\title{
Analisis Perbedaan Kinerja Keuangan Rumah Sakit Sebelum dan Sesudah Kebijakan Tanpa Uang Muka
}

\author{
Arifin $^{1 *}$, Amal Chalik Sjaaf ${ }^{2}$
}

\begin{abstract}
The upfront payment policy in the hospital caused controversy and rejection from the society. To anticipate this, some hospitals apply no upfront payment policy. However the policy causes an increase in bad debts. Seeing this dilemma, the authors will conduct research to analyze the different of hospital financial performance before and after no upfront payment policy. The research method used is comparative descriptive with analyzed by paired sample t-test. The result was no upfront payment policy has a positive impact on hospital financial performance. The results of this study were expected to be an input for hospital management and government to revise and refine on the upfront payment policy.
\end{abstract}

Keywords: financial performance, hospital, non upfront payment policy

Undang - Undang nomor 36 tahun 2009 menyatakan bahwa kesehatan merupakan hak asasi manusia dan salah satu unsur kesejahteraan yang harus diwujudkan sesuai dengan cita - cita bangsa Indonesia. ${ }^{1}$ Undang - Undang nomor 44 tahun 2009 menyebutkan bahwa rumah sakit diselenggarakan berasaskan Pancasila dan didasarkan kepada nilai kemanusiaan, etika dan profesionalitas, manfaat, keadilan, persamaan hak dan anti diskriminasi, pemerataan, perlindungan dan keselamatan pasien, serta mempunyai fungsi sosial. ${ }^{2}$

Pada bulan September 2017 rakyat Indonesia dikejutkan kembali oleh kasus kematian seorang bayi di salah satu rumah sakit swasta. Bayi tersebut diduga tidak mendapat penanganan optimal karena terhambat masalah uang muka. Kejadian ini memunculkan gelombang protes dari masyarakat yang menolak kebijakan uang muka di rumah sakit. ${ }^{3}$

Kasus bayi tersebut membangkitkan kembali ingatan publik pada sejumlah kejadian yang sama antara lain penolakan seorang pasien yang sudah didiagnosis menderita penyakit jantung, dan banyak kasus lainnya. ${ }^{4}$ Yayasan Lembaga Konsumen Indonesia menilai kebijakan uang muka merupakan suatu ironi, rumah sakit yang seharusnya dikelola dengan asas kemanusiaan dan tolong menolong justru mendahulukan kepentingan komersial. ${ }^{5}$

\footnotetext{
Penulis untuk korespondensi :dr.arifin@gmail.com

Rumah Sakit Santa Maria Pekanbaru

2 Dosen Program Studi S2 KARS FKM Universitas Indonesia
}

Laura Goodhue, Direktur Eksekutif Florida Chain, sebuah organisasi advokasi konsumen kesehatan di Palm Beach menyatakan bahwa meminta pembayaran sebelum memulai perawatan memberi tekanan bagi pasien-pasien, terutama pada kasus kegawatdaruratan yang mengancam jiwa. ${ }^{6} \mathrm{Di}$ sisi lain, rumah sakit memiliki pengalaman buruk berupa piutang tidak tertagih, gangguan likuiditas, dan penurunan profit margin yang mengancam operasional rumah sakit. Masalah utama yang mendorong penelitian studi kasus ini adalah penolakan kebijakan uang muka bagi pasien rawat inap oleh masyarakat. Penolakan ini disebabkan karena adanya kasus pasien yang telantar, masyarakat memiliki pengalaman jelek dengan rumah sakit, banyak berita negatif tentang rumah sakit di media, masyarakat berasumsi rumah sakit tidak mematuhi undang - undang, dan bersifat komersial. Di sisi lain rumah sakit memiliki pengalaman berupa tagihan yang tidak dilunasi pasien sehingga mengakibatkan peningkatan piutang dan gangguan likuiditas rumah sakit. ${ }^{7}$ Jika masalah ini tidak segera diatasi, masyarakat akan menghindari rumah sakit yang menerapkan kebijakan uang muka sehingga jumlah pasien akan turun dan menimbulkan peningkatan risiko terhadap kinerja keuangan rumah sakit. $^{8}$

Obyek penelitian dibatasi pada perbedaan kinerja keuangan Rumah Sakit Swasta X di Pekanbaru sebelum kebijakan tanpa uang muka 
(2007 - 2011) dan sesudah kebijakan tanpa uang muka (2012 - 2016). Undang -Undang Republik Indonesia Nomor 44 Tahun 2009 tentang rumah sakit telah mengatur secara terperinci fungsi sosial rumah sakit, antara lain pelayanan gawat darurat tanpa uang muka. ${ }^{2}$

Masalah timbul ketika pasien gawat darurat membutuhkan penanganan lanjutan di rawat inap. Sebagian besar rumah sakit memiliki kebijakan mewajibkan pembayaran uang muka sebelum pasien dipindah ke ruangan. ${ }^{8} \mathrm{Hal}$ ini disebabkan pengalaman rumah sakit berupa tagihan yang tidak dilunasi pasien, sehingga sebagian besar rumah sakit menerapkan kebijakan uang muka bagi pasien rawat inap. Salah satu kunci untuk bertahan bagi rumah sakit adalah dengan meminimalkan piutang tak tertagih yang bisa dicegah dengan menerapkan kebijakan uang muka. ${ }^{9}$

Hal ini didukung oleh beberapa penelitian yang menunjukkan bahwa pembayaran uang muka berpengaruh terhadap piutang tidak tertagih, ada korelasi antara debt ratio dengan likuiditas dan rasio profitabilitas. ${ }^{10}$ Kinerja keuangan rumah sakit dapat diukur dengan menggunakan rasio keuangan. ${ }^{11}$

Menurut James O Gill, rasio keuangan terdiri dari : dari :

Rasio Likuiditas (Liquidity Ratio) yang terdiri

- Rasio Lancar (Current Ratio), merupakan rasio untuk mengukur kemampuan perusahaan dalam membayar kewajiban jangka pendek atau utang yang segera jatuh tempo. Rasio ini dapat digunakan untuk mengukur tingkat keamanan (margin of safety) suatu perusahaan. Perhitungan rasio lancar dilakukan dengan cara membandingkan antara total aktiva lancar dengan total utang lancar.

- Rasio Perputaran Kas

Rasio ini membandingkan antara kas dan aktiva lancar dengan utang lancar dan digunakan untuk mengukur kemampuan perusahaan dalam membayar kewajiban yang harus segera dipenuhi dengan aktiva lancar yang lebih likuid (liquid assets).

- Rasio Utang terhadap Kekayaan Bersih (Debt Ratio), merupakan rasio utang yang digunakan untuk mengukur perbandingan antara total utang dengan total aktiva. Apabila rasionya tinggi berarti pendanaan dengan utang semakin banyak. Perhitungan rasio ini diperoleh dari membandingkan total utang dengan total aktiva.

Rasio Profitabilitas (Profitability Ratio) yang terdiri dari :

- Margin Laba Bersih (Net Profit Margin), merupakan ukuran keuntungan dengan membandingkan antara laba setelah pajak dibandingkan dengan penjualan. Rasio ini menunjukkan pendapatan bersih perusahaan atas penjualan.

- Tingkat Laba atas Penjualan (Gross Profit Margin)

Rasio ini menunjukkan laba relatif perusahaan.

- Hasil Pengembalian Investasi (Return On Investment/ROI)

Hasil pengembalian investasi (Return on investment) merupakan rasio yang menunjukkan hasil atas jumlah aktiva yang digunakan dalam perusahaan. Rasio ini menunjukkan efektifitas perusahaan dalam mengelola investasinya.

Rasio Efisiensi (Activity Ratio) yang terdiri dari:

- Waktu Pengumpulan Piutang (Days of Receivable), merupakan rasio yang digunakan untuk mengukur berapa lama penagihan piutang selama satu periode atau berapa kali dana yang ditanam dalam piutang ini berputar dalam satu periode

- Perputaran Sediaan

Rasio yang digunakan untuk mengukur berapa kali dana yang ditanam dalam persediaan ini berputar dalam suatu periode

- Rasio Aktiva Tetap terhadap Nilai Bersih (Total Asset Turnover Ratio)

Rasio yang digunakan untuk mengukur perputaran semua aktiva yang dimiliki perusahaan

- Rasio Perputaran Investasi (Investment Turnover Ratio)

Rasio yang digunakan untuk mengukur perputaran semua aktiva yang dimiliki perusahaan. ${ }^{11}$

Asosiasi Rumah Sakit Florida, Amerika (The Florida Hospital Association) menemukan adanya 
tren permintaan uang muka sebelum perawatan di rumah sakit. Dari survei diperoleh data bahwa 14\% dari 481 rumah sakit non profit mewajibkan pasien untuk membayar uang muka sebelum perawatan. ${ }^{6}$ Di Nigeria baik di rumah sakit umum maupun swasta, pasien harus membayar uang muka terlebih dahulu sebelum mendapat perawatan. ${ }^{12}$ "Keharusan membayar uang muka juga menjadi penghalang bagi masyarakat miskin untuk mendapatkan pelayanan kesehatan di rumah sakit”. ${ }^{13}$

Gunawan WH dalam penelitian Analisis Pengaruh Kualitas Pelayanan Medis dan Pelayanan Administrasi menemukan bahwa pelayanan administrasi yang sesuai harapan memiliki korelasi positif dengan kepuasan dan loyalitas pasien. ${ }^{14}$ Sebuah Firma yang menganalisis data untuk industri kesehatan di Florida menyatakan bahwa pasien yang puas dengan pelayanan administrasi keuangan memiliki kemauan membayar yang lebih tinggi (74\% pasien membayar lunas tagihan mereka), sebanyak 82\% akan merekomendasikan rumah sakit tersebut kepada orang lain, dan 95\% akan memilih rumah sakit tersebut untuk perawatan berikutnya. ${ }^{15}$

Di sisi lain kesulitan ekonomi mengakibatkan peningkatan pasien yang tidak membayar tagihan mereka, walaupun sebagian dari biaya perawatan telah ditanggung oleh asuransi. Bloomberg Businessweek melaporkan bahwa diantara pasien yang merupakan pekerja yang memiliki asuransi, sebanyak $41 \%$ memiliki tunggakan biaya perawatan lebih dari \$1.000. ${ }^{16}$

Bahkan di Amerika yang merupakan negara maju, banyak rumah sakit memiliki piutang tak tertagih dan mulai menerapkan aturan - aturan yang ketat untuk pembiayaan pasien. ${ }^{17}$ Demikian pula halnya dengan hasil penelitian yang dilakukan pada 10 rumah sakit pendidikan di Seoul dalam kurun waktu tahun 2008 - 2011 yang menyimpulkan bahwa beberapa rumah sakit terus mengalami defisit dan penurunan total keuntungan. ${ }^{18}$

Jeff Buehrle, Chief Financial Officer dari Banner-University Medicine, Arizona mengatakan bahwa tahun 2014, Banner Health memiliki \$140 juta piutang tidak tertagih yang menjadi dasar untuk menerapkan kebijakan uang muka di rumah sakit. ${ }^{19}$ Hasil penelitian di Rumah Sakit Jantung dan Pembuluh Darah Harapan Kita menunjukkan bahwa uang muka berpengaruh signifikan terhadap piutang pasien tak tertagih, di mana semakin banyak jumlah pasien yang tidak membayar uang muka semakin tinggi jumlah piutang tak tertagih. ${ }^{20}$

\section{METODE}

Metode penelitian yang digunakan adalah metode deskriptif komparatif dengan pendekatan kuantitatif. Penelitian ini dilakukan di Rumah Sakit Santa Maria Pekanbaru yang merupakan Rumah Sakit Swasta dengan tipe B (sesuai dengan Keputusan Menteri Kesehatan Republik Indonesia Nomor : HK.03.05/I/961/2011 tanggal; 12 April 2011).

Dilakukan perbandingan kelompok data laporan keuangan yaitu: VariabelS1 : Sebelum diberlakukan Kebijakan Tanpa Uang Muka untuk Seluruh Jenis Pelayanan (dari tahun 2007 sampai dengan tahun 2011) dan Variabel S2 : Sesudah diberlakukan Kebijakan Tanpa Uang Muka untuk Seluruh Jenis Pelayanan (dari tahun 2012 sampai dengan tahun 2016).

Perbandingan data laporan keuangan di awali dengan menghitung rasio keuangan menggunakan rumus sebagai berikut :

Rasio Lancar $($ Current Ratio $)=\frac{\text { Total aktiva lancer }}{\text { Total kewajiban lancer }}$

Perputaran Kas $=\frac{\text { Kas }+ \text { Bank }+ \text { Deposito }}{\text { Total kewajiban lancer }}$

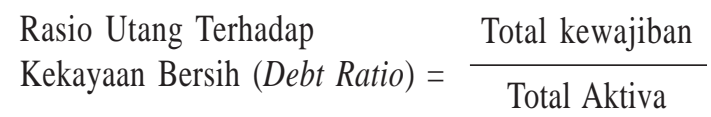

Margin Laba Bersih Laba bersih setelah pajak

$($ Net Profit Margin $)=\quad$ Penjualan bersih
Tingkat Laba Atas Penjualan (Gross Profit Margin $)=$

Hasil Pengembalian Investasi $($ Return On Investment/ ROI $)=$
Laba kotor

Penjualan Bersih

Laba bersih setelah pajak

Total Aktiva 
Waktu Pengumpulan Piutang Piutang dagang x 365 hari per tahun (Days of Receivable = penjualan bersih

Perputaran Persediaan

HPP

(Inventory Turn Over) $=$

Persediaan Rata-rata

Rasio Aktiva Tetap terhadap

Nilai Bersih (Total Asset Turnover Ratio) =
Rasio Perputaran Investasi (Investment Turnover Ratio) =

$$
\frac{\text { Penjualan Bersih }}{\text { Total Aktiva Tetap }}
$$

Uji statistik dengan menggunakan paired sample t-test antara variabel rasio keuangan sebelum dan sesudah kebijakan tanpa uang muka dengan tingkat signifikansi á =0,05.

\section{HASIL}

Hasil penelitian menunjukkan data rasio keuangan Rumah Sakit Swasta X di Pekanbaru sebagai berikut:

Tabel 1. Perbandingan Rasio Keuangan Rumah Sakit Santa Maria Pekanbaru Sebelum dan Sesudah

\begin{tabular}{|c|c|c|c|c|c|c|c|c|c|c|c|c|}
\hline \multirow[b]{2}{*}{ Rasio Keuangan } & \multicolumn{6}{|c|}{ 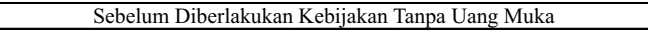 } & \multicolumn{6}{|c|}{ Sesudah Diberlakukan Kebijakan Tanpa Uang Muka } \\
\hline & $\begin{array}{l}\text { Tahun } \\
2007\end{array}$ & $\begin{array}{l}\text { Tahun } \\
2008\end{array}$ & $\begin{array}{l}\text { Tahun } \\
2009\end{array}$ & $\begin{array}{l}\text { Tahun } \\
2010\end{array}$ & $\begin{array}{l}\text { Tahun } \\
2011\end{array}$ & $\begin{array}{l}\text { Rata - rata } \\
2007 \mathrm{sd} 2011\end{array}$ & $\begin{array}{l}\text { Tahun } \\
2012\end{array}$ & $\begin{array}{l}\text { Tahun } \\
2013\end{array}$ & $\begin{array}{l}\text { Tahun } \\
2014\end{array}$ & $\begin{array}{l}\text { Tahun } \\
2015\end{array}$ & $\begin{array}{l}\text { Tahun } \\
2016\end{array}$ & $\begin{array}{c}\text { Rata - rata } \\
2012 \text { sd } 2016\end{array}$ \\
\hline \multicolumn{13}{|c|}{ Rasio Likuiditas } \\
\hline $\begin{array}{l}\text { Rasio Lancar (Current } \\
\text { Ratio) }\end{array}$ & $167 \%$ & $58 \%$ & $74 \%$ & $123 \%$ & $166 \%$ & $118 \%$ & $149 \%$ & $234 \%$ & $418 \%$ & $630 \%$ & $947 \%$ & $476 \%$ \\
\hline Rasio Perputaran Kas & $38 \%$ & $29 \%$ & $34 \%$ & $85 \%$ & $109 \%$ & $59 \%$ & $111 \%$ & $191 \%$ & $377 \%$ & $597 \%$ & $892 \%$ & $434 \%$ \\
\hline $\begin{array}{l}\text { Rasio Utang Terhadap } \\
\text { Kekayaan Bersih (Debt } \\
\text { Ratio) }\end{array}$ & $25,06 \%$ & $32,19 \%$ & $30,39 \%$ & $26,48 \%$ & $26,44 \%$ & $28,11 \%$ & $27,21 \%$ & $23,29 \%$ & $15,48 \%$ & $11,86 \%$ & $8,34 \%$ & $17,23 \%$ \\
\hline \multicolumn{13}{|c|}{ Rasio profitabilitas } \\
\hline $\begin{array}{l}\text { Margin Laba Bersih (Net } \\
\text { Profit Margin) } \\
\text { Tingkat Laba Atas }\end{array}$ & $3,70 \%$ & $3,25 \%$ & $4,22 \%$ & $5,63 \%$ & $6,51 \%$ & $4,66 \%$ & $6,49 \%$ & $10,27 \%$ & $10,27 \%$ & $10,48 \%$ & $11,60 \%$ & $9,82 \%$ \\
\hline $\begin{array}{l}\text { Penjualan (Gross Profit } \\
\text { Margin) }\end{array}$ & $66,77 \%$ & $65,61 \%$ & $66,47 \%$ & $67,00 \%$ & $66,19 \%$ & $66,41 \%$ & $69,94 \%$ & $71,75 \%$ & $73,96 \%$ & $74,38 \%$ & $75,81 \%$ & $73,17 \%$ \\
\hline $\begin{array}{l}\text { Hasil Pengembalian } \\
\text { Investasi (Return On } \\
\text { Investment/ROI) }\end{array}$ & $7,43 \%$ & $7,40 \%$ & $11,25 \%$ & $15,53 \%$ & $16,84 \%$ & $11,69 \%$ & $15,70 \%$ & $17,64 \%$ & $17,64 \%$ & $17,03 \%$ & $15,41 \%$ & $16,68 \%$ \\
\hline \multicolumn{13}{|c|}{ Rasio Efisiensi } \\
\hline $\begin{array}{l}\text { Waktu Pengumpulan } \\
\text { Piutang (Days of } \\
\text { Receivable) }\end{array}$ & 17 & 14 & 14 & 11 & 11 & 13 & 12 & 13 & 10 & 7 & 6 & 10 \\
\hline $\begin{array}{l}\text { Perputaran Persediaan } \\
\text { (Inventory Turn Over) }\end{array}$ & 55 & 63 & 70 & 53 & 74 & 63 & 52 & 38 & 41 & 49 & 22 & 40 \\
\hline $\begin{array}{l}\text { Ratio Aktiva Tetap } \\
\text { terhadap Nilai Bersih } \\
\text { (Total Asset Turn Over) }\end{array}$ & $78 \%$ & $120 \%$ & $111 \%$ & $92 \%$ & $76 \%$ & $95 \%$ & $82 \%$ & $57 \%$ & $42 \%$ & $29 \%$ & $23 \%$ & $46 \%$ \\
\hline $\begin{array}{l}\text { Rasio Perputaran Investasi } \\
\text { (Investment Turn Over } \\
\text { Ratio) }\end{array}$ & $201 \%$ & $228 \%$ & $266 \%$ & $276 \%$ & $259 \%$ & $246 \%$ & $234 \%$ & $216 \%$ & $198 \%$ & $163 \%$ & $133 \%$ & $189 \%$ \\
\hline
\end{tabular}
diberlakukan Kebijakan Tanpa Uang Muka 
Tabel 2.Paired Samples Test

\begin{tabular}{|c|c|c|c|c|c|c|c|c|c|}
\hline \multicolumn{10}{|c|}{ Paired Samples Test } \\
\hline & & \multirow[b]{3}{*}{ Mean } & \multicolumn{4}{|c|}{ Paired Differences } & \multirow[b]{3}{*}{$\mathrm{t}$} & \multirow[b]{3}{*}{$\mathrm{df}$} & \multirow{3}{*}{$\begin{array}{c}\text { Sig. } \\
\text { (2-tailed) }\end{array}$} \\
\hline & & & \multirow{2}{*}{$\begin{array}{c}\text { Std. } \\
\text { Deviation }\end{array}$} & \multirow{2}{*}{$\begin{array}{l}\text { Std. Error } \\
\text { Mean }\end{array}$} & \multicolumn{2}{|c|}{ Difference } & & & \\
\hline & & & & & Lower & Upper & & & \\
\hline $\begin{array}{l}\text { Rasio Lancar (Current } \\
\text { Ratio) }\end{array}$ & $\begin{array}{c}\text { Sebelum Kebijakan Tanpa Uang Muka - } \\
\text { Sesudah Kebijakan Tanpa Uang Muka }\end{array}$ & $-358,00000$ & 306,52325 & 137,08136 & $-738,59888$ & 22,59888 & $-2,612$ & 4 & ,059 \\
\hline Rasio Perputaran Kas & $\begin{array}{l}\text { Sebelum Kebijakan Tanpa Uang Muka - } \\
\text { Sesudah Kebijakan Tanpa Uang Muka }\end{array}$ & $-374,60000$ & 284,09030 & 127,04905 & $-727,34470$ & $-21,85530$ & $-2,948$ & 4 &, 042 \\
\hline $\begin{array}{l}\text { Rasio Utang Terhadap } \\
\text { Kekayaan Bersih(Debt } \\
\text { Ratio) }\end{array}$ & $\begin{array}{l}\text { Sebelum Kebijakan Tanpa Uang Muka - } \\
\text { Sesudah Kebijakan Tanpa Uang Muka }\end{array}$ & 10,87600 & 8,00091 & 3,57811 & ,94156 & 20,81044 & 3,040 & 4 &, 038 \\
\hline $\begin{array}{l}\text { Margin Laba Bersih }(\mathrm{Net} \\
\text { Profit Margin })\end{array}$ & $\begin{array}{l}\text { Sebelum Kebijakan Tanpa Uang Muka - } \\
\text { Sesudah Kebijakan Tanpa Uang Muka }\end{array}$ & $-5,16000$ & 1,57873 &, 70603 & $-7,12026$ & $-3,19974$ & $-7,308$ & 4 & ,002 \\
\hline $\begin{array}{l}\text { Tingkat Laba Atas } \\
\text { Penjualan (Gross Profit } \\
\text { Margin) }\end{array}$ & $\begin{array}{l}\text { Sebelum Kebijakan Tanpa Uang Muka - } \\
\text { Sesudah Kebijakan Tanpa Uang Muka }\end{array}$ & $-6,76000$ & 2,36482 & 1,05758 & $-9,69631$ & $-3,82369$ & $-6,392$ & 4 &, 003 \\
\hline $\begin{array}{l}\text { Hasil Pengembalian } \\
\text { Investasi (Return On } \\
\text { Investment } / \text { ROI) }\end{array}$ & $\begin{array}{l}\text { Sebelum Kebijakan Tanpa Uang Muka - } \\
\text { Sesudah Kebijakan Tanpa Uang Muka }\end{array}$ & $-4,99400$ & 4,83935 & 2,16422 & $-11,00285$ & 1,01485 & $-2,308$ & 4 & 082 \\
\hline $\begin{array}{l}\text { Waktu Pengumpulan } \\
\text { Piutang (Days of } \\
\text { Receivable) }\end{array}$ & $\begin{array}{l}\text { Sebelum Kebijakan Tanpa Uang Muka - } \\
\text { Sesudah Kebijakan Tanpa Uang Muka }\end{array}$ & 3,80000 & 1,64317 &, 73485 & 1,75974 & 5,84026 & 5,171 & 4 &, 007 \\
\hline $\begin{array}{l}\text { Perputaran Persediaan } \\
\text { (Inventory Turnover) }\end{array}$ & $\begin{array}{l}\text { Sebelum Kebijakan Tanpa Uang Muka - } \\
\text { Sesudah Kebijakan Tanpa Uang Muka }\end{array}$ & 22,60000 & 20,25586 & 9,05870 & $-2,55098$ & 47,75098 & 2,495 & 4 &, 067 \\
\hline $\begin{array}{l}\text { Ratio Aktiva Tetap } \\
\text { terhadap Nilai Bersih } \\
\text { (Total Asset Turnover) }\end{array}$ & $\begin{array}{l}\text { Sebelum Kebijakan Tanpa Uang Muka - } \\
\text { Sesudah Kebijakan Tanpa Uang Muka }\end{array}$ & 48,80000 & 30,06992 & 13,44768 & 11,46326 & 86,13674 & 3,629 & 4 &, 022 \\
\hline $\begin{array}{l}\text { Rasio Perputaran } \\
\text { Investasi (Investment } \\
\text { Turnover Ratio) }\end{array}$ & $\begin{array}{l}\text { Sebelum Kebijakan Tanpa Uang Muka - } \\
\text { Sesudah Kebijakan Tanpa Uang Muka }\end{array}$ & 57,20000 & 67,34761 & 30,11876 & $-26,42310$ & 140,82310 & 1,899 & 4 & ,130 \\
\hline
\end{tabular}

Pada tabel 2. terlihat hasil rasio lancar (current ratio), hasil pengembalian investasi (return on investment/ ROI), perputaran persediaan (inventory turnover), rasio perputaran investasi (investment turnover ratio) tidak terdapat perbedaan signifikan. Sedangkan rasio perputaran kas, rasio utang terhadap kekayaan bersih (debt ratio), margin laba bersih (net profit margin), tingkat laba atas penjualan (gross profit margin), waktu pengumpulan piutang (days of receivable), dan rasio aktiva tetap terhadap nilai bersih (total asset turnover), terdapat perbedaan signifikan sebelum dan sesudah kebijakan tanpa uang muka.

\section{PEMBAHASAN}

Hasil penelitian tidak terdapat perbedaan rasio keuangan yang signifikan dalam hal rasio lancar, hasil pengembalian investasi, perputaran persediaan dan rasio perputaran investasi, namun terdapat perbedaan rasio keuangan yang signifikan pada rasio perputaran kas, rasio utang terhadap kekayaan bersih, net profit margin, gross profit margin, waktu pengumpulan piutang, dan total asset turnover. Secara keseluruhan terdapat peningkatan kinerja keuangan setelah penerapan kebijakan tanpa uang muka, yaitu terjadi peningkatan likuiditas, peningkatan profitabilitas dan waktu pengumpulan piutang yang semakin pendek.

Hasil penelitian ini bertolak belakang dengan penelitian Mac Donald yaitu kebijakan tanpa uang muka mengakibatkan rumah sakit mengalami gangguan likuiditas dan penurunan profit margin. ${ }^{7}$ Selain itu juga bertentangan dengan hasil penelitian Paimin di Rumah Sakit Jantung dan Pembuluh Darah Harapan Kita di Jakarta, semakin banyak pasien yang tidak membayar uang muka semakin tinggi jumlah piutang tidak tertagih. ${ }^{20}$

Hasil penelitian ini sejalan dengan hasil penelitian Marisola di Florida yang menyatakan bahwa pasien yang puas dengan pelayanan administrasi keuangan memiliki kemauan membayar lebih tinggi, akan merekomendasikan rumah sakit tersebut kepada orang lain dan akan memilih rumah sakit tersebut untuk perawatan berikutnya, yang tentunya akan memberi dampak positif bagi kinerja keuangan rumah sakit. ${ }^{15}$ 


\section{KESIMPULAN}

Hasil penelitian yang dilakukan di Rumah Sakit Swasta X di Pekanbaru dengan mengambil data sekunder dari tahun 2007 - 2016 menunjukkan hasil bahwa secara keseluruhan terdapat perbedaan kinerja keuangan rumah sakit antara sebelum dengan sesudah kebijakan tanpa uang muka yaitu terjadinya peningkatan pada likuiditas dan profitabilitas serta waktu pengumpulan piutang yang semakin pendek setelah menerapkan kebijakan tersebut.

\section{DAFTAR PUSTAKA}

1. Republik Indonesia. Undang-undang Nomor 36 tahun 2009 tentang Kesehatan. Lembaran Negara Republik Indonesia Tahun 2009 Nomor 144. Sekretariat Negara. Jakarta. 2009.

2. Republik Indonesia. Undang-undang Nomor 44 tahun 2009 tentang Rumah Sakit. Lembaran Negara Republik Indonesia Tahun 2009 Nomor 153. Sekretariat Negara. Jakarta; 2009.

3. Nailufar, Nibras Nadah. Soal meninggalnya bayi Debora, Dinkes Akan Panggil Manajemen RS Mitra Keluarga. Kompas.com. 2017; . https:// megapolitan.kompas.com/read/2017/09/09/ 20232261/soal-meninggalnya-bayi-deboradinkes-akan-panggil-manajemen-rsmitra[diakses 5 Desember 2017].

4. Rahadian, Lalu. Ragam kasus mirip bayi Debora. CNN Indonesia. 2017; https:// www.cnnindonesia.com/nasional/ 20170912100017-20-241097/ragam-kasus-miripbayi-debora[diakses 5 Desember 2017].

5. YLKI : Kasus bayi Debora ironi Rumah Sakit.CNN Indonesia. 2017; https:// www.cnnindonesia.com/nasional/ 20170911070536-20-240829/ylki-kasus-bayidebora-ironi-rumah-sakit[diakses 5 Desember 2017].

6. Torbati, June. Sign in and pay now: Insured patients finding they must put down higher fees upfront for care: More hospitals want payment before treatment. McClatchy - Tribune Business News. Washington. 2008.

7. MacDonald, Illene. Hospitals seek patient collection strategies: Cash upfront, payment plans. Fierce Health Finance. Newton. 2013. https://www.fiercehealthcare.com/finance/ hospital-seek-patient-collection-strategies-Cashupfront-payment-plan[diakses 5 Desember 2017].

8. Suntoro, Agus. Kisah bayi Debora dan pentingnya implementasi hak atas kesehatan. Kompas.com.2017; http://megapolitas. kompas. com/read/2017/09/22585741/kisah-bayi-deboradan-pentingnya-implementasi-Hak-AtasKesehatan[diakses 18 Januari 2018].

9. Barkholz, Dave.Moving patient payment upfront. Chicago. Modern HealthcareVol. 46, Iss. 21: 2223. 2016; http://www.modernhealthcare.com/ article/20160521/M A G A Z I N E/ 305219931[diakses 15 Desember 2017].

10.Bem, Agniezka. Predkiewiez, Katarzyna. Predkiewiez, Pawel Paulina. Jez, Ucieklak. Determinats of Hospital's Financial Liquidity.Czech Republic. Procedia Economics and Finance 12 (27 - 36). 2014; https:// www.sciencedirect.com/science/article/pii/ $\underline{\text { S2212567114003177[diakses } 15 \text { Desember }}$ 2017].

11. Kasmir. Analisis laporan keuangan. Raja Grafindo Persada. Jakarta. 2016

12. Aregbeshola, Bolaji Samson.Out-of-pocket payments in Nigeria. The Lancet Vol. 387, Iss. 10037; 2506. London. 2016; http:// www.thelancet.com/journals/lancet/article/ PIIS0140-6736(16)30798-X/fulltext[diakses 15 Desember 2017].

13.Lestari, Tri Rini Puji. Pelayanan rumah sakit bagi masyarakat miskin (studi kasus di enam wilayah Indonesia). KESMAS, Jurnal Kesehatan Masyarakat Nasional Vol. 5, No. 1. 2010; https:/ /media.neliti.com/media/publications/39638-IDpelayanan-rumah-sakit-bagi-masyarakat-miskinstudi - kasus - di - en a m - wila yah indones.pdf[diakses 25 Oktober 2017].

14. Gunawan, Wely Hadi. Analisis pengaruh kualitas pelayanan medis dan pelayanan administrasi terhadap loyalitas pasien (studi pada pasien rawat inap Cirebon).2013; http://eprints.undip.ac.id/ 42128/[diakses 6 September 2017]. 
15. Marisola, Laura J. Payment clarity improves upfront collections, patient satisfaction: Patient access at front and center for bottom-line success. Healthcare registration Vol. 25 no.5). 2016.

16. Shinkman, Ron. (2014,Oct 2). More hospital seek upfront payment from patient. Newton.FierceHealthFinance. 2014; https:// www.fiercehealthcare.com/finance/morehospitals-seek-upfront-payments-from-patients [diakses 5 Desember 2017].

17. Sweeney, Brigid. More hospital getting stiffed on patient bills : It's not just the poor. With high deductible plans, the middle class are doing it, too. Chicago. Crain's Chicago Business 40, Iss. 13: 1. 2017; http://www.modernhealthcare.com/ staff/chicago-business [diakses 5 Desember 2017].
18.Lee,Munjae.Financial analysis of national university hospitals in Korea. Elsevier Korea LLC. 2016; https://www.ncbi.nlm.nih.gov/pmc/ articles/PMC4677494/pdf/main.pdf.[diakses 5 Desember 2017].

19.Innes, Stephanie. (2015, Jun 20). Pay upfront or no surgery, cancer patient is told. Chicago. TCA Regional News. September 6, 2017. http:// tucson.com/news/local/pay-upfront-or-nosurgery-cancer-patient-is-told/article acfa9374cf63-5934-8375-c5a76596df78.html[diakses 6 September 2017].

20.Paimin. Pengaruh pasien masuk rawat, lepas rawat, uang muka dan jenis pembiayaan terhadap piutang tak tertagih periode tahun 2011-2013 (Studi kasus pada rumah sakit jantung dan pembuluh darah harapan kita Jakarta). 2015; $\underline{\text { http:/ }}$ /repository.mercubuana. ac.id/7650/[diakses 5 Desember 2017]. 